\title{
Implementasi Nilai-Nilai Tri Kaya Parisudha dalam pembelajaran dengan Model Pembelajaran Numbered Head Together Berpengaruh Terhadap Kompetensi Pengetahuan IPS
}

\author{
I Made Diantara Adi Putra ${ }^{1 *}$, Ni Wayan Rati², I Nyoman Laba Jayanta ${ }^{3}$ (i) \\ ${ }^{123}$ Prodi Pendidikan Guru Sekolah Dasar, Universitas Pendidikan Ganesha, Singaraja, Indonesia \\ *Corresponding author: gonokadiputra@gmail.com
}

\begin{abstract}
Abstrak
Hasil belajar IPA sebagian besar siswa yang masih rendah, mendorong perlunya menciptakan proses pembelajaran yang dapat mengatasi permasalahan tersebut. Salah satu caranya, yaitu dengan menggunakan model pembelajaran NHT Berlandaskan Tri Kaya Parisudha. Penelitian ini bertujuan untuk mengetahui perbedan yang signifikan hasil belajar IPA antara kelompok siswa yang dibelajarkan dengan model pembelajaran Numbered Head Together berlandasakan Tri Kaya Parisudha dengan kelompok siswa yang tidak dibelajarkan model pembelajaran Numbered Head Together berlandaskan Tri Kaya Parisudha pada siswa Kelas IV SD. Penelitian ini merupakan eksperimen semu (Quasi Eksperimen) dengan rancangan non equivalent post-test only control grup design. Populasi penelitian berjumlah 180 siswa dan sampel penelitian ini berjumlah 46 siswa yang ditentukan dengan teknik simpel random sampling. Pengumpulan data dilakukan dengan tes hasil belajar IPA yang berupa tes objektif. Data dianalisis menggunakan analisis deskriptif dan Independent Sample t-test. Uji t diperoleh nilai signifikansi 2 arah (2-tailed) $0,000<0,05$ sehingga terdapat perbedaan skor yang berarti antara kelompok kelas kontrol dan eksperimen. Dengan demikian, terdapat perbedaan yang signifikan hasil belajar IPA antara kelompok siswa yang dibelajarkan menggunakan model pembelajaran Numbered Head Together berlandaskan Tri Kaya Parisudha dan siswa yang dibelajarkan menggunakan pembelajaran konvensional pada siswa kelas IV SD. Implikasi pada penelitian ini adalah dengan dilakukan penerapan model NHT Berlandaskan Tri Kaya Parisudha pada mata pelajaran IPA yaitu, pembelajaran di kelas untuk membuat siswa menjadi tidak mudah bosan di kelas.
\end{abstract}

Keywords: NHT, IPA, Tri Kaya Parisudha

\section{Abstract}

Science learning outcomes of most students are still low, encouraging the need to create a learning process that can overcome these problems. One way is to use the NHT learning model based on the Tri Kaya Parisudha. This study aims to determine the significant difference between science learning outcomes between groups of students who are taught with the Numbered Head Together learning model based on Tri Kaya Parisudha with groups of students who are not taught the Numbered Head Together learning model based on Tri Kaya Parisudha students in Class IV SD. This research is a quasiexperimental (Quasi Experiment) with a non equivalent post-test only control group design. The study population was 180 students and the sample of this study amounted to 46 students who were determined by a simple random sampling technique. Data collection is done by science learning outcomes test in the form of objective tests. Data were analyzed using descriptive analysis and Independent Sample t-test. The t test obtained 2-tailed significance value of 0,000 <0.05 so that there was a significant difference in scores between the control class and the experimental group. Thus, there are significant differences in science learning outcomes between groups of students who are taught using the Numbered Head Together learning model based on Tri Kaya Parisudha and students who are taught using conventional learning in class IV elementary students. The implication of this research is the application of the NHT model based on the Tri Kaya Parisudha on science subjects, that is, learning in class to make students not easily get bored in class.

Keywords: NHT, Sciences, Tri Kaya Parisudha

\section{Pendahuluan}

Pendidikan adalah hal yang sangat penting bagi manusia khususnya di Negara Indonesia, karena melalui pendidikan bisa menghasilkan sumber daya manusia yang bisa bersaing ditingkat nasional maupun internasional. Menurut Dewi dkk (2014:2) mendefinisikan "pendidikan dapat pula dikatakan sebagai investasi jangka panjang yang memerlukan usaha dan dana yang cukup besar, hal ini demi kemajuan suatu bangsa". Mahardika dkk (2018) mengatakan pendidikan merupakan usaha sadar untuk mewujudkan

History:

Received: 4 Maret 2020

Revised: 15 Maret 2020

Accepted: 26 Maret 2020

Published: 1 April 20200 
suasana belajar yang membuat siswa menjadi aktif dalam proses pembelajaran. Salah satu muatan pembelajaran yang wajib dibelajarkan di SD adalah IPA. IPA merupakan mata pelajaran yang mempelajari berbagai gejala alam. Menurut Menaka \& Japa (2016:3) "IPA merupakan kumpulan pengetahuan yang berupa fakta, yang menekankan proses pembelajaran yang mempelajari lingkungan atau alam yang ada disekitar siswa". Yanthi dkk (2017) menyatakan IPA merupakan ilmu tentang peristiwa-peristiwa yang terjadi di alam. Ratih (2017:2) menyatakan"IPA di SD bertujuan agar siswa mempunyai pengetahuan, gagasan dan konsep yang terorganisasi tentang alam sekitar, yang diperoleh dari pengalaman melalui serangkaian proses ilmiah seperti penyelidikan, penyusunan dan penyajian gagasangagasan". Agustinus., dkk (2016) mengatakan bahwa, mata pelajaran IPA sangat berperan penting dalam membentuk karakter peserta didik, karena dalam ilmu pengetahuan alam diperlukan mengkaji, mengamati dan melakukan observasi sehingga perlu pemikiran yang terstruktur. Witari dkk (2017) menyatakan pembelajaran IPA dapat menjadi wahana bagi siswa untuk mempelajari diri sendri serta lingkungan di sekitar sehingga akan membantu dalam kehidupan sehari-hari. Dengan diajarkan dari awal peserta didik berpikir secara struktural sehingga dapat terlatih dikemudian hari.

Namun kenyataan dilapangan menunjukan kemampuan IPA siswa tergolong rendah. Hal ini terlihat dari hasil survei PISA tahun 2018 untuk kategori sains menunjukan, Indonesia masih jauh di bawah rata-rata skor OECD sebesar 489, sedangkan skor rata-rata indonesia adalah 396 (Permana, 2019). Sedangkan menurut hasil survei TIMSS tahun 2015 khususnya untuk bidang sains Indonesia berada pada peringkat 45 dari 48 negara. Rata-rata skor Indonesia adalah 397. Jika dibandikan dengan kriteria capaian TIMSS, maka rata-rata skor Indonesia tergolong pada kategori rendah (Hadi, S., dan Novaliyosi, 2019). Selain itu, melalui studi dokumen yang dilakukan pada kelas IV SD di Gugus VI Kecamatan Buleleng, menunjukan sebagian besar hasil belajar IPA siswa asih dibawah KKM. Berikut disajikan nilai rata-rata UTS siswa SD kelas IV di Gugus VI Kecamatan Buleleng.

Tabel 1. Nilai Rata-rata UTS Siswa SD Kelas IV di Gugus VI Kecamatan Buleleng Kabupaten Buleleng Tahun Pelajaran 2019/2020

\begin{tabular}{lccccccc}
\hline No & Nama Sekolah & $\begin{array}{c}\text { Kelas } \\
\end{array}$ & $\begin{array}{c}\text { Jumlah } \\
\text { Siswa }\end{array}$ & $\begin{array}{c}\text { Rata-rata } \\
\text { Nilai Ulangan } \\
\text { IPA }\end{array}$ & $\begin{array}{c}\text { Di bawah } \\
\text { KKM }\end{array}$ & $\begin{array}{c}\text { Di atas } \\
\text { KKM }\end{array}$ & KKM \\
\hline 1 & SD N 1 Kampung Baru & IV & 23 & 67,5 & 13 & 10 & 68 \\
2 & SD N 2 Kampung Baru & IV & 14 & 65 & 8 & 6 & 65 \\
3 & SDN 3 Kampung Baru & IV & 33 & 67,3 & 17 & 16 & 68 \\
4 & SD N 4 Kampung Baru & IV A & 28 & 70 & 5 & 23 & 65 \\
& SD N 4 Kampung Baru & IV B & 23 & 62.9 & 15 & 8 & 65 \\
5 & SD N 5 Kampung Baru & IV & 30 & 67,2 & 16 & 14 & 70 \\
6 & SD N 7 Kampung Baru & IV & 29 & 64,9 & 17 & 12 & 63 \\
\hline \multicolumn{7}{c}{ Jumlah } & \multicolumn{18}{c}{}
\end{tabular}

(Sumber: Wali Kelas IV di Gugus VI Kecamatan Buleleng Kabupaten Buleleng)

Berdasarkan Tabel 1 di atas, maka dapat dilihat hasil belajar pada mata pelajaran IPA siswa kelas IV SD di Gugus VI Kecamatan Buleleng, Kabupaten Buleleng masih kurang baik. Hal ini dapat dilihat dari jumlah siswa yang nilainya belum memenuhi KKM lebih banyak dibandingkan dengan jumlah siswa nilainya memenuhi KKM. Selain itu, nilai ratarata ujian tengah semester yang diperoleh sebagian besar siswa masih di bawah KKM. Mmelalui kegiatan observasi dikelas IV SD pada Gugus VI Kecamatan Buleleng Kabupaten Buleleng, didapatkan fakta yaitu, (1) guru menjelaskan materi pada saat proses pembelajaran 
masih monoton menggunakan metode ceramah. (2) guru tidak menggunakan media saat menjelaskan materi, sehingga pembelajaran yang terjadi di dalam kelas kurang meraik bagi siswa. (3) hasil belajar pada mata pelajaran IPA kurang dari KKM. Hal ini karena siswa tidak berdiskusi secara aktif dan hanya mendengarkan ceramah dari guru sehingga siswa menjadi pasif pada saat guru menjelaskan di depan kelas. Adanya permasalah yang sudah dipaparkan di atas, maka perlu diterapkan model pembelajaran yang dapat meningkatkan hasil belajar IPA.Yanti (2016) menyatakan hasil belajar menjadi tolak ukur yang dapat menunjukkan pemahaman siswa setelah mengikuti proses pembelajaran. Dayanthi dkk, (2017) menyatakan hasil belajar yang tinggi dapat diperoleh apabila interaksi antara guru dan siswa terjalin dengan baik. Salah satu solusi yang dapat ditawarkan ialah dengan menerapkan model pembelajaran Numbered Head Together (NHT).

Menurut Candra., dkk (2014:2) "dalam model pembelajaran Numbered Head Together (NHT) siswa dituntut untuk bekerja sama saling membantu dan berdiskusi dalam kelompok guna memecahkan masalah yang diberikan dan semua siswa harus mampu menemukan jawabanya". Trianto (dalam Yanti, dkk., 2016) berpendapat Numbered Head Together atau penomeran berpikir bersama merupakan salah satu jenis pembelajaran kooperatif yang dirancang agar merubah pola interaksi siswa. Dadri \& Putra (2017) menyatakan penggunaan model pembelajaran Numbered Head Together membuat siswa menggali sendiri pengetahuan baru bersama kelompok. Selain itu, Paramita dkk (2016) menyatakan interaksi siswa menjadi aktif dalam berdiskusi mengenai materi yang diajarkan dengan menggunakan model pembelajaran Numbered Head Together sehingga siswa akan dapat memahami materi menggunakan caranya sendiri dan akan mudah diingat. Hurianti \& Tastra, (2018) mengatakan dengan menggunakan model pembelajaran Numbered Head Togetherakan melatih siswa untuk mendengarkan dengan seksama, berbicara dengan perhitungan yang matang dan saling berbagi informasi yang membuat siswa menjadi aktif.

Model pembelajaran Numbered Head Together memiliki beberapa fase yang dilalui dalam proses pembelajaran. Menurut Trianto (2010) model pembelajaran Numbered Head Together memiliki empat fase, yaikni: 1) fase penomoran dalam fase ini, guru membagi siswa ke dalam kelompok; 2) fase memberikan pertanyaan, dalam fase ini guru memberikan pertanyaan pada semua siswa; 3) fase berfikir bersama, dalam fase ini siswa menyatukan pendapatnya terhadap jawaban yang dimiliki oleh siswa; 4) fase menyampaikan jawaban, fase ini guru memanggil satu nomor untuk menjawab pertanyaan yang sudah diberikan. Untuk mencapai tujuan pembelajaran, ada beberapa hal yang harus dilakukan dalam proses belajar berkelompok adalah berpikir, berkata, dan berbuat yang baik untuk dapat memecahkan masalah yang diberikan. Hasil penelitian Mulyana dkk (2016) menunjukan, model kooperatif tipe Numbered Head Together (NHT) dapat meningkatkan hasil belajar siswa pada materi kenampakan alam dan sosial budaya. Menurut Wati \& Fatimah (2016) terdapat peningkatan kemampuan berpikir kritis siswa seiring diterapkannya model kooperatif tipe Numbered Head Together. Lebih lanjut, Lagur dkk (2018) menyebutkan pengimplementasian model kooperatif tipe Numbered Head Together dapat meningkatkan keteramilan komunikasi matematika siswa. Selanjutnya hasil penelitian Nur \& Salam (2016) juga menyatakan model pembelajaran kooperatif tipe Numbered Head Together (NHT) berpengaruh terhadap hasil belajar matematika siswa.

Selain penggunaan model pembelajaran kooperatif tipe Numbered Head Together untuk mencapai tujuan pembelajaran, ada beberapa hal yang harus dilakukan dalam proses belajar berkelompok adalah berpikir, berkata, dan berbuat yang baik untuk dapat memecahkan masalah yang diberikan. Oleh karena itu dalam model Numbered Head Together perlu dilandaskan ajaran agama Hindu Tri Kaya Parisudha. Menurut Suratmini (dalam Candra, D., dkk., 2014) menyatakan, Tri Kaya Parisudha merupakan tiga dasar perilaku manusia yang harus disucikan bagi agama hindu di bali,dari tiga dasar perilaku 
tersebut terdiri dari. Manacika berarti berpikiran yang baik, Wacika berarti berkata yang baik dan Kayika berarti perbuatan yang baik. Adanya pikiran yang baik akan mendasari perkataan yang baik, sehingga terciptanya perbuatan yang baik pula. Oleh karena itu perkataan dan perbuatan yang baik bersumber dari pikiran yang baik.Suhardana (dalam Astawan, 2018:39) mengemukakan "Tri Kaya Parisudha artinya tiga perbuatan manusia berupa pikiran, perkataan, dan prilaku yang harus disucikan". Sukadi, dkk. (dalam Astawan, 2018) menyatakan "Tri Kaya Parisudha yaitu manacika diartikan sebagai kemapuan berpikir yang baik, benar, dan bijaksana; wacika diartikan sebagai berkata-kata yang jujur, benar, objektif, dan menyejukkan: dan kayika diartikan sebagai kemapuan berprilaku atau berbuat yang baik dan benar serta selalu membahagiakan orang lain”. Selamet (2017) menyatakan Tri Kaya Parisudha adalah tiga macam laksana yang baik dalam berpikir, berkata dan berbuat yang baik sesuai norma yang berlaku di masyarakat. Hasil penelitian Artini, dkk (2016) menunjukan penerapan model pembelajaran think talk write berbasis kearifan lokal Tri Kaya Parisudha berpengaruh positif terhadap hasil belajar IPA siswa. Somawati \& Made (2019) pengimplementasian ajaran Tri Kaya Parisudha dalam kehidupan sehari-hari sangat relevan untuk membentuk generasi muda Hindu yang baik, serta menjauhkan diri dari hal-hal negatif yang merupakan dampak dari perkembangan era digital seperti saat ini. Lebih lanjut, Adnyana \& Citrawathi (2017) menyatakan medel pendidikan karakter berbasis Tri Kaya Parisudha efektif dalam menanamkan karakter meliputi: berpikir positif, religius, keyakinan terhadap hukum karmapala, berkata sopan, berkata jujur, kasih sayang, berbuat jujur, peduli, dan disiplin. Selanjutnya, hasil penelitian Artawan \& Ardiawan (2018) menjelaskan nilai karakter yang berbasis Tri Kaya Parisudha yang terintegrasikan tercermin dalam pembelajaran quantum teaching yakni menciptakan suasana belajar yang mendukung tercapainya penguasaan konsep siswa.

Penelitian ini bertujuan untuk mengetahui pengaruh yang signifikan hasil belajar IPA antara kelompok siswa yang dibelajarkan dengan model pembelajaran Numbered Head Together berlandaskan Tri Kaya Parisudha dengan kelompok siswa yang tidak dibelajarkan model pembelajaran Numbered Head Together berlandaskan Tri Kaya Parisudha pada siswa kelas IV SD. Perbedaan penelitian ini dengan penelitian sejenis, yaitu pengimplementasian model pembelajaran Numbered Head Together dilandasi dengan ajaran Tri Kaya Parisudha

\section{Metode}

Penelitian ini merupakan eksperimen semu (Quasi Eksperimen). Karena tidak semua variabel yang muncul dan kondisi eksperimen dapat diatur dan dikontrol secara ketat. Penelitian ini menggunakan rancangan non equivalent post-test only control grup design. Menurut Riduwan (2013), Populasi merupakan objek atau subjek yang berada pada suatu wilayah dan memenuhi syarat-syarat tertentu untuk dijadikan masalah penelitian. Populasi dalam penelitian ini adalah seluruh kelas IV SD di Gugus VI Kecamatan Buleleng Kabupaten Buleleng yang berjumlah 180 siswa. Jumlah SD keseluruhan di Gugus VI Kecamatan Buleleng Kabupaten Buleleng sebanyak 6 SD. Untuk mengetahui kemampuan pada masingmasing siswa di SD Gugus VI Kecamatan Buleleng Kabupaten Buleleng setara atau tidak, maka seluruh anggota populasi diuji kesetaraan dan kemampuannya dengan cara menganalisis nilai Ulangan Tengah Semester pada mata pelajaran IPA dengan menggunakan rumus Anava Satu Jalur. Berdasarkan hasil uji kesetaraan pada taraf signifikan 5\% diperoleh

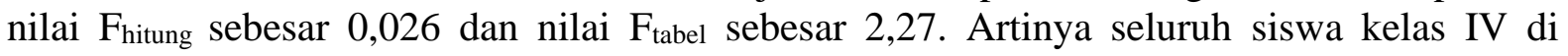
Gugus VI Kecamatan Buleleng Kabupaten Buleleng memiliki kemampuan akademik yang setara. Setelah melakukan uji kesetaraan akan dilanjutkan dengan penentuan sampel. Agung (2014:48) menyatakan bahwa sampel penelitian adalah sebagian dari populasi yang diambil, yang dianggap mewakili seluruh populasi dan diambil menggunakan teknik tertentu. Sampel pada penelitian ini diambil menggunakan teknik simpel random sampling. Setelah dilakukan 
teknik simpel random sampling didapat kelompok eksperimen SD Negeri 1 Kampung Baru dengan jumlah siswa 23 dan sampel kelompok kontrol SD Negeri 4 Kampung Baru Kelas IV B dengan 23 siswa.

Dalam penelitian ini, metode yang digunakan untuk mengumpulkan data adalah metode tes, dengan jenis tes menggunakan tes pilihan ganda dengan 30 soal. Tes hasil belajar yang dibuat disesuaikan dengan indikator yang mengacu pada taksonomi bloom dengan retangan tingkat kognitif mulai dari C1- C6. Tes hasil belajar IPA yang telah selesai disusun kemudian harus melalui beberapa uji sebelum digunakan. Pertama dilakukan uji validitas isi oleh pakar yang membidangi IPA. Perhitungan uji validitas isi mengunakan rumus Gregory dan hasilnya intrumen yang dibuat memiliki koefisien 1,00 yang berarti instrumen ini termasuk dalam kategori sangat baik. Kedua dilakukan reliabilitas tes dengan skor 0,767. Berdasarkan hasil tersebut berarti instrument hasil belajar IPA memiliki reliabilitas tinggi. Selanjutnya dilakukan uji daya beda, Dari hasil penghitung uji daya beda, sesuai dengan kateria klasifikasi untuk uji daya beda pada 35 butir soal, 1 butir soal yang dikatan kriteria sangat jelek, 8 butir soal dengan kriteria jelek, 7 butir soal dengan kriteria cukup, 16 butir soal dengan kriteria baik, dan 3 butir soal dengan kreteria sangat baik. Selanjutnya dilakukan uji tingkat kesukaran, Berdasarkan perhitungan tingkat kesukarn butir sol sebanyak 35 butir soal, diproleh 3 butir soal dengan kreteria sukar, 14 butir soal dengan kriteria sedang, dan 18 butir soal dengan kriteria mudah. Selanjutnya analisis statistik deskriptif yang digunakan yaitu, skor rata-rata (mean) tiap-tiap variabel dikonversikan dengan menggunakan kriteria rata-rata ideal (Mi) dan standar deviasi ideal (SDi), serta untuk menentukan skala penilaian lima. Sedangkan uji prasyarat yang harus dipenuhi sebelum melakukan analisis data utama untuk menguji hipotesis penelitian yaitu uji normalitas sebaran data ditiap kelompok dan uji homogentitas varians antar kelompok. Uji hipotesis yang digunakan adahah uji-t.

\section{Hasil dan Pembahasan}

Hasil penelitian ini adalah hasil analisis data skor hasil belajar IPA berdasarkan analisis statirtik deskriptif dan analisis statisik analisis inferensial. Hasil deskripsi data pada penelitian ini disajikan ke dalam Tabel 2.

Tabel 2. Hasi Uji Deskriptif, Uji Prasyarat Analisis, dan Uji Hipotesis

\begin{tabular}{ccc}
\hline Variabel & Kelas Kontrol & Kelaas Eksperimen \\
\hline Mean & 22 & 25 \\
Median & 23,71 & 26,71 \\
Modus & 23,5 & 26,5 \\
Standar Deviasi & 2,13 & 2,13 \\
Varians & 4,54 & 4,54 \\
Skor Maksimum & 26 & 29 \\
\hline Skor Minimum & $\mathbf{1 8}$ & $\mathbf{2 1}$
\end{tabular}

Berdasarkan Tabel 2, rata-rata hasil belajar IPA kelompok ekserimen adalah 25 dengan kategori sangan baik sedangkan kelompok kontrol memiliki rata-rata 22 dengan kategori baik. Pada kelompok ekksperimen memiliki median dan modus sebesar 26,71 dan 26,5 sedangkan pada kelompok komtrol memiliki median dan modus sebesar 23,71 dan 23,5. Besar standar deviasi dan varians kelompok eksperimen adalah 2,13 dan 4,54 sedangkan besar standar deviasi dan varians kelompok kontrol adalah 2,13 dan 4,54. Setelah dilakukan analisis deskriptif data, dilanjutjan dengan uji prasyarat data yang meliputi uji normalitas dan homogenitas menggunakan bantuan SPSS. Hasil akhir uji normalitas data disajikan ke dalam Tabel 3 . 
Tabel 3. Hasiakhir Uji Normalitas Data

\begin{tabular}{ccccccc}
\hline & \multicolumn{3}{c}{ Kolmogorov-Smirnov $^{\text {a }}$} & \multicolumn{3}{c}{ Shapiro-Wilk } \\
\hline & Statistic & Df & Sig. & Statistic & df & Sig. \\
\hline $\begin{array}{c}\text { Skor_Kontrol } \\
\text { Skor_Eksperime } \\
\text { n }\end{array}$ & 0,115 & 23 & $0,200^{*}$ & 0,974 & 23 & 0,774 \\
\hline
\end{tabular}

Berdasarkan Tabel 3, diketahui bahwa nilai Sig. Skor Kelas Kontrol dan eksperimen sebesar 0.200 dan 0.774 dimana > 0.05. Maka sesuai dengan dasar pengambilan keputusan dalam uji normalitas Kolmogorov-smirnov, dapat disimpulkan bahwa data skor kelas control dan eksperimen berdistribusi normal. Dengan demikian persyaratan atau asumsi normalitas terpenuhi.Selanjutnya, hasil akhir uji homogenitas varians data hasil belajar IPA akan disajikan ke dalam tabel 4.

Tabel 4. Hasi akhir Uji Homogenitas Varians Data

\begin{tabular}{cccc}
\hline \multicolumn{4}{c}{ Test of Homogeneity of Variances } \\
\hline Skor & df1 & df2 & Sig. \\
Levene Statistic & 1 & 44 & 1,000 \\
0,000 & &
\end{tabular}

Berdasarkan rekapitulasi hasil uji homogenitas pada tabel 4 menunjukkan hasil dari uji homogenitas dengan metode Levene's Test. Diperoleh nilai Sig. 1.000 dimana > 0.05 yang berarti terdapat kesamaan varians (homogen) antar kelompok. Dengan demikian, persyaratan atau asumsi data homogen terpenuhi. Berdasarkan uji normalitas dan homogenitas varians, maka dapat dilakukan uji hipotesis menggunakan uji t. Hasil uji t adalah nilai signifikansi 2 arah (2-tailed) 0,000 < 0,05 sehingga terdapat perbedaan skor yang berarti antara kelompok kelas kontrol dan eksperimen. Maka sebagaimana dasar pengambilan keputusan dalam uji independent sample t-test dapat disimpulkan bahwa $\mathrm{H} 0$ ditolak dan $\mathrm{H} 1$ diterima.

Berdasarkan analisis penelitian, dapat diketahui bahwa terdapat pengaruh model pembelajaran Numbered Head Together berlandaskan Tri Kaya Parisudha terhadap hasil belajar IPA siswa di kelas IV SD di Gugus VI Kecamatan Buleleng. Tinjauan ini didasarkan dari hasil uji-t diperoleh nilai signifikansi 2 arah (2-tailed) sebesar 0,000 pada taraf signifikansi $5 \%(0,000<0,05)$ sehingga terdapat perbedaan skor yang berarti antara kelompok kelas kontrol dan eksperimen. Adapun perbedaan rata-rata skor hasil belajar IPA kedua kelompok, hasil belajar IPA dibelajarkan menggunakan model pembelajaran Numbered Head Together berlandaskan Tri Kaya Parisudha lebih tinggi sebesar 25 dibanding dengan hasil belajar IPA yang tidak menggunakan model Numbered Head Together berlandaskan Tri Kaya Parisudha sebesar 22. Hasil penelitian ini didukung oleh penelitian Dewi dkk (2014) yang menunjukkan terdapat perbedaan hasil belajar IPA pada rata-rata nilai post test antara kelompok siswa yang belajar dengan model pembelajaran Numbered Head Together (NHT) berlandaskan Tri Kaya Parisudha dengan kelompok siswa yang belajar dengan model pembelajaran konvensional.

Perbedaan tersebut disebabkan beberapa hal. Model pembelajaran Numbered Head Together berlandaskan Tri Kaya Parisudha merupakan model pembelajarn yang menuntut siswa untuk menggali pengetahuan dan keterampilannya sendiri. Melalui model pembelajaran Numbered Head Together siswa dapat menggali pengetahuannya sendiri dengan memecahkan masalah yang diberikan guru. Model pembelajar Numbered Head 
Together membuat siswa tertarik perhatiannya dengan guru menggunakan media berupa LKPD sehingga siswa sibuk untuk mengerjakan dan menggali pengetahuan dari diskusi yang dilakukan. Hal ini sejalan dengan pendapat Selamet (2017) bahwa pembelajaran menggunakan model Numbered Head Together siswa dituntut untuk bisa bekerjasama dalam kelompok masing-masing dengan melakukan interaksi antar siswa yang mencakup makna siswa harus berpikir yang baik untuk bisa berkata yang baik maupun berbuat yang baik. Model pembelajaran Numbered Head Together berlandaskan Tri Kaya Parisudha membantu siswa mengatasi kesulitan belajar dengan bekerja secara berkempok. Setelah siswa menemukan masalah maka akan bekerja bersama kelompoknya masing-masing sehingga mampu menghasilkan kesimpulan dari permasalahan yang diberikan. Siswa akan mampu menuangkan ide-ide dan bertukar pendapat bersama dengan kelompok sehingga pembelajaran berpusat pada siswa. Yanti (2016) mengatakan pembelajaran menggunakan model Numbered Head Together berlandaskan Tri Kaya Parisudha dapat meningkatkan keterlibatan semua siswa dalam dan bertanggung jawab dalam kelompok untuk menyelesaikan permasalahan yang diberikan sehingga dapat menambah pengetahuan baru yang akan membantu memperoleh hasil belajar yang baik.

Kelebihan lain dengan berlandaskan Tri Kaya Parisudha adalah pada wacika membuat siswa tertarik untuk mengikuti pembelajaran dengan berusaha mencari masalah yang diberikan. Kemudian selanjutnya pada manacika, siswa dapat menyelesaikan masalah yang diberikan bersama kelompok sehingga mampu menemukan konsep baru. Ditemukannya konsep dan terpecahkannya masalah sehingga siswa mampu memberi kesimpulan (kayika). Sehingga pengetahuan menjadi lebih bermakna dan diingat lebih lama. Selain itu hasil belajar IPA siswa menjadi lebih baik karena siswa lebih aktif berdiskusi, memecahkan masalah, dan menyampaikan simpulan yang diperoleh. Perbedaan hasil belajar IPA antara siswa yang dibelajarkan dengan menggunakan model Numbered Head Together berlandaskan Tri Kaya Parisudha dengan yang tidak dibelajarkan menggunakan model Numbered Head Together berlandaskan Tri Kaya Parisudha disebabkan beberapa faktor. Menurut Dewi dkk (2014) adanya perbedaan hasil belajar IPA antara kelompok siswa yang dibelajarkan menggunakan model pembelajaran Numbered Head Together berlandaskan Tri Kaya Parisudha dengan kelompok siswa yang tidak dibelajarkan menggunakan model pembelajaran Numbered Head Together berlandaskan Tri Kaya Parisudha disebabkan oleh beberapa faktor, seperti motivasi, interaksi, aktivitas, dan tanggung jawab selama pembelajaran.

Pertama, motivasi belajar siswa. Pada saat menggunakan model pembelajaran Numbered Head Together berlandaskan Tri Kaya Parisudha motivasi siswa menjadi meningkat dalam mengikuti proses pemlajaran. Hal ini ditunjukkan saat proses pembelajaran siswa sangat antusias dalam melaksanakan diskusi bersama kelompok mengenai materi yang diajarkan dengan bahasa yang baik sehingga tidak menyinggung satu sama lain. Motivasi ini timbul karena setiap siswa ingin menjadi terbaik saat mewakili kelompoknya menjawab soal yang diberikan guru. Hal ini sejalan dengan hasil penelitian dari Susillo (2013) yaitu motivasi belajar siswa setelah mengikuti pembelajaran model kooperatif tipe Numbered Head Together meningkat. Hal ini sesuai dengan pendapat (Sardiman, 2011: 92) bahwa ada beberapa cara untuk menumbuhkan motivasi siswa dalam belajar, antara lain memberi angka, hadiah, kompetisi, ego-involvement, member ulangan, mengetahui hasil, pujian, hukuman, hasrat belajar, minat, dan tujuan yang diakui.

Kedua, interaksi siswa selama pembelajaran. Pada saat pembelajaran dengan Numbered Head Together berlandaskan Tri Kaya Parisudha terlihat interaksi antar siswa menjadi lebih aktif. Siswa saling membantu dalam memecahkan masalah yang diberikan dalam LKPD. Siswa yang menganggap dirinya belum mengerti tidak malu menanyakan pada teman yang sudah mengerti. Demikian halnya yang sudah mengerti tidak merasa keberatan mengajari temannya yang belum mengerti. Sehingga interaksi antar siswa sangat aktif 
membahas mengenai materi. Sejalan dengan pendapat (Faridli, 2014:55) bahwa pembelajaraan kooperatif merupakan sistem pengajaran yang memberi kesepatan kepada anak didik untuk bekerja sama dengan sesama siswa dalam tugas-tugas yang terstruktur. Model Number Head Together berpengaruh terhadap komunikasi antar siswa, hal ini sejalan dengan hasil penelitian dari Lagur dkk. (2018) yaitu kemampuan komunikasi matematis siswa yang diajarkan dengan menerapkan model pembelajaran kooperatif tipe NHT meningkat menjadi lebih intensif. Selain itu dengan model number head together siswa menjadi lebih aktif berinteraksi dengan temanya, hal ini selaras dengan hasil penelitian oleh Hartarto (2015) yaitu model pembelajaran NHT dapat meningkatkan keaktifan siswa dalam pem-belajaran matematika siswa kelas VII-B SMP PGRI Bruno.

Hal ketiga yang ditemukan pada siswa yang dibelajarkan dengan model pembelajaran Numbered Head Together berlandaskan Tri KayaParisudha aktivitas siswa menjadi meningkat dalam mendiskusikan materi. Siswa berani mengungkapkan pendapatnya saat diskusi dan siswa yang belum paham tidak malu bertanya sehingga siswa memperoleh pengetahuan baru dengan caranya sendiri sehingga akan mudah untuk diingat dan dipahami. Sardiman (2011:97) mengungkapkan dalam proses pembelajaran diperlukan adanya aktivitas, tanpa adanya aktivitas pembelajaran tidak dapat berjalan dengan baik. Keempat, tanggung jawab yang dimiliki siswa meningkat. Pada prmbalajaran menggunakan model Numbered Head Together berlandaskan Tri Kaya Parisudha siswa dituntut untuk bertanggung jawab terhadap kelompok masing-masing karena pembelajaran dilaksanakan secara berkelompok. Pada saat nomor siswa yang ditunjuk sebagai perwakilan kelompoknya akan berusaha untuk menjawab supaya mendapat hasil yang baik bagi dirinya dan kelompok. Shoimin (2014) menyatakan pembelajaran model Numbered Head Together merupakan pembelajaran berkelompok yang setiap anggota kelompoknya bertanggung jawab atas tugas kelompoknya, sehingga semua siswa aktif untuk memikirkan jawaban dari soal yang diberikan oleh guru. dalam suatu kelompok untuk saling member jawaban dan menerima jawaban antara siswa satu dengan siswa yang lainya.

Hasil penelitian ini didukung oleh beberapa hasil penelitian adalah hasil penelitian oleh Yanti, (2016:6) yang menyatakan bahwa, terdapat perbedaan yang signifikan hasil belajar IPA antar kelompok siswa yang mengikuti pembelajaran kooperatif Numbered Head Together (NHT) dengan kelompok siswa yang mengikuti pembelajaran model konvensional. Selanjutnya, hasil penelitian oleh Selamet, N.W, dkk., (2017:11) yaitu terdapat perbedaan yang signifikan antara siswa yang dibelajarkan menggunakan model Numbered Head Together (NHT) berbasis Kearifan Lokal Tri Kaya Parisudha berpengaruh terhadap hasil belajar IPS siswa dan siswa yang tidak dibelajarkan dengan model pembelajaran Numbered Head Together berbasis Kearifan Lokal Tri Kaya Parisudha. Selain itu, hasil penelitian oleh Sastrawan (2014:88) yaitu terdapat perbedaan yang signifikan hasil belajar IPA antara siswa yang mengukuti pembelajaran dengan model pembelajaran kooperatif tipe Numbered Head Together dengan berbantuan media software dan siswa yang mengikuti pembelajaran menggunakan model pembelajaran konvensional.

Berbeda halnya pada kelompok kontrol yang tidak dibelajarkan menggunakan model Numbered Head Together berlandaskan Tri Kaya Parisudha, pembelajaran masih berpusat pada guru, komunikasi selama pembelajaran cenderung satu arah dari guru ke siswa. Sehingga siswa hanya memperhatikan guru menjelaskan di depan kelas. Kegiatan pembelajaran ini membuat siswa menjadi pasif dan mudah bosan dan tidak bersemangat, maka siswa lebih sulit untuk memahami materi yang diajarkan guru. Sehingga berpengaruh terhadap pemahaman materi siswa yang berdampak pada hasil belajar yang menjadi buruk. Berdasarkan hal tersebut maka, model berpengaruh baik dan baik gunakan untuk meningkatkan hasil belajar IPA siswa atau mata pelajaran lainnya yang sejenis. 


\section{Simpulan}

Simpulan penelitian ini adalah terdapat perbedaan yang signifikan hasil belajar IPA antara kelompok siswa yang dibelajarkan menggunakan Numbered Head Together berlandaskan Tri Kaya Parisudha dengan siswa yang dibelajarkan menggunakan pembelajaran konvensional pada siswa kelas IV SD di Gugus VI Kecamatan Buleleng Kabupaten Buleleng. Implikasi pada penelitian ini adalah dengan dilakukan penerapan model Numbered Head Together berlandaskan Tri Kaya Parisudha pada mata pelajaran IPA dapat meningkatkan kerjasama, melatih siswa menyampaikan pendapat, meningkatkan kemampuan berpikir kritis, dapat membantu susana belajar yang efektif dan membuat siswa aktif didalam proses pembelajaran.

\section{Daftar Pustaka}

Astuti, Y., Syahrilfuddin, \& Marhadi, H. (2016). Penerapan model pembelajaran kooperatif tipe numbered heads together (nht) Untuk meningkatkan hasil belajar matematika siswa kelas iii sdn 150 pekanbaru. Journal of Basication (JOB) : Jurnal Pendidikan Dasar, 1(3), 130. https://doi.org/10.36709/jobpgsd.v1i3.14373.

Dewi, A. A. I. R. M., Murda, I. N., \& Tegeh, I. M. (2014). Pengaruh Model VCT Berlandaskan Konsep Tri Kaya Parisudha Terhadap Hasil Belajar Ranah Afektif Siswa Kelas V Di SD Gugus III Kecamatan Seririt Kabupaten Buleleng Tahun Pelajaran 2013/2014. Mimbar PGSD Undiksha, 2(1). https://doi.org/http://dx.doi.org/10.23887/jjpgsd.v2i1.2430.

Dwicahyani, N. M., Wiarta, I. W., \& Ardana, I. K. (2019). Penerapan Model Pembelajaran Nht Berbantuan Media Gambar Meningkatkan Penguasaan Kompetensi Ips. Journal for Lesson and Learning Studies, 2(1), 102-110. https://doi.org/10.23887/jlls.v2i1.17326.

Fatimah, S. (2017). Analisis Pemahaman Konsep IPA Berdasarkan Motivasi Belajar, Keterampilan Proses Sains, Kemampuan Multirepresentasi, Jenis Kelamin, Dan Latar Belakang Sekolah Mahasiswa Calon Guru SD. Jurnal Inovasi Pendidikan Dan Pembelajaran Sekolah Dasar, 1(1), 57-70. https://doi.org/10.24036/jippsd.v1i1.7934.

Hadiyati, N., \& Wijayanti, A. (2017). Keefektifan Metode Eksperimen Berbantu Media Benda Konkret Terhadap Hasil Belajar IPA Siswa Kelas V Sekolah Dasar. JIPVA (Jurnal Pendidikan IPA Veteran), 1(1), 24-31. https://doi.org/10.31331/jipva.v1i1.513.

Jahring, J. (2020). Kemampuan Koneksi Matematis Pada Model Pembelajaran CORE Dan NHT. AKSIOMA: Jurnal Program Studi Pendidikan Matematika, 9(1), 182-189. https://doi.org/10.24127/ajpm.v9i1.2667.

Kurnia, V. T., Damayani, A. T., \& Kiswoyo, K. (2019). Keefektifan Model Pembelajaran Number Head Together (NHT) Berbantu Media Puzzle Terhadap Hasil Belajar Matematika. Jurnal Ilmiah Sekolah Dasar, 3(2), 192. https://doi.org/10.23887/jisd.v3i2.17772.

Kusumawati, H., \& Mawardi, M. (2016). Perbedaan Penerapan Model Pembelajaran Kooperatif Tipe NHT Dan STAD Ditinjau Dari Hasil Belajar Siswa. Scholaria: Jurnal Pendidikan Dan Kebudayaan, 6(3), 251-263. https://doi.org/10.24246/j.scholaria.2016.v6.i3.p251-263.

Lasfeto, A. R. (2017). Meningkatkan Hasil Belajar Ipa Melalui Model Group Investigation Berbantuan Video Pada Siswa Sekolah Dasar. Jurnal Penelitian Dan Pengembangan Pendidikan, 1(3), 1-7. https://doi.org/10.23887/jppp.v1i3.12631.

Marasiwi, M. (2017). Penerapan Model Pembelajaran Kooperatif Tipe Numbered Heads Together (NHT) Untuk Meningkatkan Prestasi Belajar Matematika Siswa. Premiere Educandum, 7(1), 19-27. https://doi.org/10.25273/pe.v7i01.1140. 
Mariana, P., \& Riwayati. (2016). Perbedaan Hasil Belajar Menggunakan Model Pembelajaran Numbered Heads Together (NHT) Dengan Think Pair Share (TPS) Pada Materi Ekosistem Dikelas VII. Jurnal Pelita Pendidikan, 4(2), 86-92. https://doi.org/10.24114/jpp.v4i2.4048.

Maryoto, G. (2018). Pengaruh Pembelajaran Kooperatif Tipe Think-Pair-Share (Tps) Dan Numbered-Heads-Together (Nht) Terhadap Motivasi Dan Hasil Belajar Matematika. Jurnal Pendidikan, 17(2), 121-128. https://doi.org/10.33830/jp.v17i2.271.2016.

Muliandari, P. T. V. (2019). Pengaruh Model Pembelajaran Kooperatif Tipe NHT (Numbered Head Together) Terhadap Hasil Belajar Matematika. International Journal of Elementari Education, 3(2), 132-140. https://doi.org/10.23887/ijee.v3i2.18517.

Murwanto, S. (2020). Implementasi Model Pembelajaran Kooperatif Tipe NHT (NumberedHead-Together) untuk Meningkatkan Hasil Belajar IPA Siswa Kelas IX B SMP Negeri 4 Alla Enrekang. Jurnal Sainsmat, 9(1), 14-28. https://doi.org/10.35580/sainsmat91141872020.

Mustika, D. (2017). Pembelajaran Menggunakan Model Learning Cycle 5E Untuk Meningkatkan Hasil Belajar IPA Di Sekolah Dasar. Jurnal Handayani: Jurnal Kajian Pendidikan Pra Sekolah Dan Pendidikan Dasar, 7(2), 1-8. https://doi.org/10.24114/jh.v7i2.7230.

Nasrulloh, F. (2017). Keefektifan model kooperatif tipe tps dan nht ditinjau dari prestasi belajar matematika siswa kelas xi. Eduscope, 03(01). https://doi.org/10.32764/eduscope.v3i1.181.

Nurhayati, E. (2019). Penerapan Buku Saku dengan Pendekatan Saintifik untuk Meningkatkan Motivasi dan Hasil Belajar Siswa Pasca Gempa Bumi. Jurnal Kependidikan, 5(2), 94-99. https://doi.org/10.33394/jk.v5i2.1804.

Prakoso, G. A. (2015). Keefektifan Model Pembelajaran Pair Check Dan Numbered-Heads Together (NHT) Ditinjau Dari Hasil Belajar Dalam Pembelajaran IPS Kelas 4 SDN Gugus Mahesa Jenar Ambarawa. Scholaria: Jurnal Pendidikan Dan Kebudayaan, 5(3), 100-119. https://doi.org/10.24246/j.scholaria.2015.v5.i3.p100-119.

Rahmi, S. O., \& Adnan, F. (2019). Penerapan Model Pembelajaran Kooperatif Tipe Numbered Head Together (NHT) Terhadap Hasil Belajar Siswa Kelas IV SDN 43 Sungai Sapih Padang. Jurnal Basicedu, 3(2), 666-673. https://doi.org/10.31004/basicedu.v3i2.53.

Suanthara, I. N. D. E. (2018). Pengaruh Model Pembelajaran Tri Kaya Parisudha Terhadap Prestasi Belajar Mahasiswa Semester V Prodi Pendidikan Agama Hindu STKIP Agama Hindu Singaraja Tahun Akademik 2016/2017. Pasupati: Journal of Hindu Studies \& Ducation, 5(2). https://doi.org/10.37428/pspt.v5i2.31.

Suarjana, I. M., Dibia, I. K., \& Sariani, N. L. A. (2018). Pengaruh Model Pembelajaran CTL Berorientasi Tri Kaya Parisudha terhadap Hasil Belajar Matematika. International Journal of Elementary Education., 2(2), 86-95. https://doi.org/10.23887/pips.v2i2.2893.

Sulastri, S. (2020). Peningkatan Kemandirian Belajar IPA dengan Penerapan Model Pembelajaran Numbered Heads Together pada Siswa Kelas V SDN 43 Rejang Lebong. PENDIPA Journal of Science Education, 4(3), 46-51. https://doi.org/10.33369/pendipa.4.3.46-51.

Suryanata, I. K. A. (2017). Pengaruh Model Pembelajaran Kooperatif Tipe Teams Games Tournament Terhadap Hasil Belajar Matematika. JKPM (Jurnal Kajian Pendidikan Matematika), 2(2), 235. https://doi.org/10.30998/jkpm.v2i2.2497.

Syah, A. (2018). Penerapan Model Pembelajaran Kooperatif Tipe NHT Untuk Meningkatkan Hasil Belajar IPS Siswa Kelas VI SD Negeri 016 Bukit Timah Kecamatan Dumai Selatan. Jurnal Pajar (Pendidikan Dan Pengajaran), 2(3), 346-350. 
Implementasi Nilai-Nilai Tri Kaya Parisudha dalam pembelajaran dengan Model Pembelajaran Numbered Head Together Berpengaruh Terhadap Kompetensi Pengetahuan IPS

https://doi.org/10.33578/Pjr.V2i3.5527.

Yupriyanti, N. L. (2015). Pengaruh Model Pembelajaran Generatif Berbantuan Media Konkret Terhadap Hasil Belajar IPA Siswa Kelas V SD Gugus 1 Manggis Kecamatan Manggis Kabupaten Karangasem Tahun Ajaran 2014/2015. Mimbar PGSD Undiksha, 3(1). https://doi.org/10.23887/jjpgsd.v3i1.4825. 